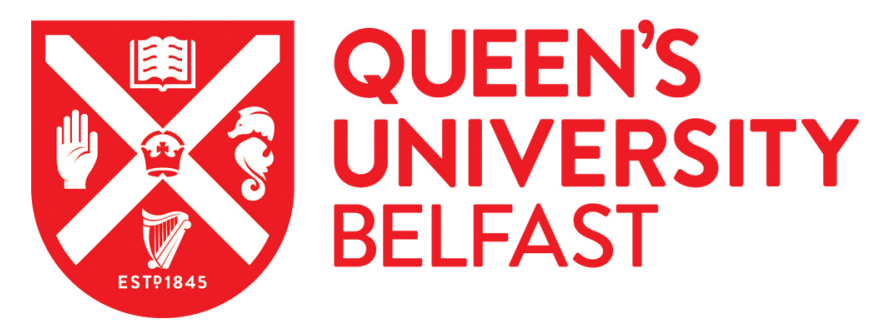

\title{
African Cinema On Demand? The Politics of Online Distribution and the Case of the African Film Library
}

Fisher, A. (2018). African Cinema On Demand? The Politics of Online Distribution and the Case of the African Film Library. Journal of African Media Studies, 10(3), 239-250. https://doi.org/10.1386/jams.10.3.239_1

Published in:

Journal of African Media Studies

Document Version:

Peer reviewed version

Queen's University Belfast - Research Portal:

Link to publication record in Queen's University Belfast Research Portal

Publisher rights

Copyright 2018 Intellect. This work is made available online in accordance with the publisher's policies. Please refer to any applicable terms of use of the publisher.

\section{General rights}

Copyright for the publications made accessible via the Queen's University Belfast Research Portal is retained by the author(s) and / or other copyright owners and it is a condition of accessing these publications that users recognise and abide by the legal requirements associated with these rights.

Take down policy

The Research Portal is Queen's institutional repository that provides access to Queen's research output. Every effort has been made to ensure that content in the Research Portal does not infringe any person's rights, or applicable UK laws. If you discover content in the Research Portal that you believe breaches copyright or violates any law, please contact openaccess@qub.ac.uk. 
African Cinema On Demand: The Politics of Online Distribution and the Case of the African Film Library

\title{
Alexander Fisher
}

\begin{abstract}
This paper considers the impact of online distribution on the long-term availability and preservation of African cinema. It examines the case of M-Net's African Film Library (AFL), a video on demand library of classic African films that was launched in 2012, but taken offline by 2013. The paper argues that this short-lived project represents a pivotal moment in the way we think about African film archiving and distribution, in which new technologies and consequently disintermediated business models promised to facilitate the circulation of African films in a manner that was socially beneficial, but which in reality resulted in monopolistic control of the content that presented a serious threat to its long-term preservation.
\end{abstract}

The paper goes on to argue that the AFL case encapsulates the entire discourse surrounding the shift to online distribution, in which a 'cybertopian' narrative of a disintermediated and thus democratized film culture quickly gives way to a reality in which content is more tightly controlled by an increasingly narrow and powerful set of private stakeholders, ultimately threatening the preservation of any content that is vulnerable to the shifting demands of the market.

\section{Keywords}

Africa; film; distribution; M-Net; archive; streaming 


\section{African Cinema On Demand: the Politics of Online Distribution and the Case of the African Film Library}

\section{Alexander Fisher}

The last ten years have seen radical transformations in the way we view cinema, with video-on-demand (VOD) progressing from a novel means of accessing film, to a mainstream platform for home viewing, supplanting much of the market that was previously dominated by DVD and VHS rentals and heralding the rise of the now-familiar services of iTunes, Netflix and Amazon Instant. Yet, these big players in the streaming industry form only a fraction of a market in which a panoply of streaming platforms have opened, ostensibly bringing a greater diversity of films to the public than ever before. This has had a particular effect on niche and peripheral material, which is now experiencing an unprecedented level of visibility and availability. Concurrently, these transformations have raised significant questions surrounding the political aspects of film distribution, especially with regard to preservation and archiving, as well as rights acquisition and gatekeeping.

African cinema forms a particularly important case within these transformations, since it is an area of global filmmaking that has, until recently, struggled to establish sustainable modes of circulation and exhibition. This is particularly true in relation to the 'canon' of African cinema (usually regarded as the international 'art' cinema tradition hailing from the West African territories and represented by auteurs such as Ousmane Sembene, Souleymane Cissé and Djibril Diop Mambéty); in contrast to the recently-emerged domestic industries organised around video films (for which Nollywood provides the archetype), the canon is often reliant on foreign distributors and confined to short runs on the art house and film festival circuits, while only rarely receiving sustained releases on video. As anyone who has sought to research African film will attest, work in this area often relies on specialised archives, repertory screenings and film festivals, with opportunities to acquire works on video (especially with subtitles) being few and far between. Beyond the canon, the domestic industries present their own particular problems in that, until recently, their distribution relied principally on the somewhat haphazard circulation of (often pirated) VHS, VCD and DVD, precluding any real scope for the long-term preservation and archiving of the material. These problems extend into our perceptions of these film cultures; for instance, anyone attempting to teach courses on African film will have seen the limited availability of subtitled material lead to a limited curriculum, with few opportunities to extend students' viewing beyond the works of a few key filmmakers.

The intense transformations brought about by online distribution initially offered a hope that these problems of visibility and availability might finally be resolved. The wider effects of these changes across film culture have, of course, been multi-faceted, but they hold a particular significance in relation to niche cinemas, especially those generally understood under the rubric of 'world cinema' (see Nagib, Perriam and Dudrah 2012: xviixxxii). One reason for this is that the online model has enabled distributors to monetize what Chris Anderson calls 'the long-tail' (Anderson, 2006: 10), which in the context of film translates into lower overheads facilitating longer distribution windows across multiple exhibition platforms, allowing peripheral or niche works to obtain a previously-elusive profitability. It is not difficult to see the positive impact this might have on the various permutations of African cinema, whose audiences are disparate and dispersed, and whose 
profitability might emerge over years, rather than months. Perhaps more significantly, these shifts have opened up channels of distribution that lend themselves to the business models of domestic cinemas in the continent (such as Nollywood), creating the potential for zero-budget productions to find affordable exhibition outlets that offer the dual advantages of the long-tail distribution model, coupled with a transnational reach to African diasporas, the latter currently benefiting from vastly superior internet coverage than the inhabitants of the producing territories themselves.

Alongside the perceived benefits of online circulation to filmmakers runs a threat to the power of the traditional distributors and gatekeepers, creating a situation characterized by Dina Iordanova as 'digital disruption' (2012: 1), bringing with it 'increased chances... for the transborder flows of niche and peripheral content' (2012: 1). The discourses that initially emerged in response to these shifts framed them within a kind of 'cybertopia'; as online exhibition moved into the mainstream and the range and diversity of platforms exploded, there promised an end to the traditional distribution structures and an emergence of a more democratic film culture, in turn generating greater exposure for marginal and niche cinemas. As Ramon Lobato observed in 2009:

According to its advocates, digital distribution will also be a boon for independent filmmakers, who will be able to cut out the middle man and deal directly with their audiences. In the words of one enthusiastic producer, 'The gatekeepers in the old days controlled everything, but with new technology there are no more gatekeepers. Everybody can get their film out. It's very democratic' (2009: 167).

Indeed, early responses to online distribution tended to follow this line of thought, concentrating on the extent to which film circulation might circumvent the distributor, placing the process into the hands of the filmmakers themselves. The most influential concept to come out of these developments has been that of 'disintermediation', described by Iordanova as '[a] process whereby direct access to content makes the intermediary in a supply chain obsolete' (2012: 3). From this somewhat utopian perspective, online distribution offers a twofold benefit to the visibility of African cinema: firstly, the capacity to turn a profit from its more niche productions due to the economics of the 'long-tail' and, secondly, the ability to disintermediate distribution, facilitating a business model that allows the dissemination of a much wider range of films, regardless (in the main) of their production and marketing budgets.

These dual benefits relate respectively to the two main modes of film practice found in Africa, which may broadly be divided into the aforementioned, 'intermediated' canonical or art house cinema on the one hand, and on the other a heterogeneous set of disintermediated domestic cinemas aimed at popular markets, pioneered by Nollywood. The Nollywood model sidestepped the traditional distributor even before the advent of streaming, with individual producers frequently undertaking distribution activities themselves via DVD and VCD (Lobato 2010: 337-354; Bischoff 2017: 262). Similarly, the subsequent online circulation of the films has tended to rely on what Lobato would classify as 'informal' outlets, largely constituted by the illegal black market of peer-to-peer networks (for example Pirate Bay), in contrast to the 'formal' outlets, legal platforms that are backed by content owners (for example Amazon Instant and Netflix) (Lobato 2010: 338). It was not until around 2010 that the first formal channels of online distribution specifically for African cinema came on-stream, a moment Stuart Cunningham and Jon Silver identify with the founding of AfricaFilms, a VOD service targeted at both African 
diasporas and world cinema enthusiasts $(2012,47)$. Significantly, the service promotes itself as a platform for emerging filmmakers in that it offers non-exclusive contracts in which producers and site owners share a 50/50 split of any profits for films uploaded to the site (Cunnigham and Silver 2012: 47). Following AfricaFilms, numerous legal sites streaming African films emerged around comparable models, including the African Movie Channel, a UK based VOD channel which primarily caters for African diasporas, as well as a plethora of informal sites such as African Movies and Vibe Ghana (Cunningham and Silver 2012: 48). The combination of formal and informal outlets thus opens up a wide range of distribution platforms whose reception extends well beyond continental borders, all of which suggests that African cinema is not only undergoing an unprecedented period of growth in terms of production, but also in terms of its global reach and address.

Thus, from this 'cybertopian' perspective, the online revolution is heralding a renaissance for African cinema, with the reduced overheads of digitised production and online distribution structuring a scenario in which it can finally establish itself as a set of genuinely independent film cultures, demonstrating its diversity at a global level, and showcasing its breadth beyond the limited set of texts that have thus far reached foreign shores. However, the negative counterbalance to this has been that - paradoxically - the canonical 'art' cinema has lost some of its visibility, as it becomes consumed in the sea of commercial productions of often-dubious quality, with the prevailing perception of African cinema now being structured around the model of Nollywood, rather than that of Sembene. An accompanying threat is the fact that film exhibition is 'now characterised by new, more accelerated distribution models in which movies move quickly from theatres (if they play on the big screen at all) to VOD and DVD before landing in DVD remainder bins at big-box stores or, perhaps more likely, archives of videos available for streaming...' (Tryon 2013: 9), thereby further reducing the potential exposure for African cinemas targeted at festival or 'art house' audiences. Indeed, some commentators have pointed to a general reduction of foreign-language cinema exhibition in movie theatres, as the VOD market generates a surfeit of productions that have crowded international films out of a marketplace that has traditionally hosted its strongest performance (Kaufman 2014). With foreign-language (read 'art house') cinema squeezed out of movie theatres and DVD releases replaced by streaming, the VOD revolution presents a new threat to the future of Africa's art film tradition, with only commercial releases set to reap the rewards.

Thus, while a proliferation of websites are hosting popular African cinemas targeted at both domestic and non-domestic audiences, to find works by Sembene, Cissé and Mambéty requires a visit to a specialized cinephile site such as Mubi, which itself has only ever shown a handful of African films, all of which have previously been available on DVD. Indeed, a brief search on Mubi does little to suggest an improvement in the availability of canonical African cinema. At the time of writing, searching for the term 'Senegal' (the native home of Sembene) does not return any African titles at all (although in the past the site has hosted Senegalese director Djibril Diop Mambéty's Touki Bouki). Thus, at least as far as Mubi is concerned, online distribution has done little to raise the availability and visibility of African cinema outside of its popular forms; indeed, the Mubi case suggests that the cinephile sites offer very few examples of the continent's cinema and - just as was the case with the orthodox distribution model - these remain hidden amongst more wellknown examples of 'world cinema' such as The Killer (John Woo, Hong Kong, 1989) and City of God (Fernando Meirelles and Kátia Lund, Brazil/France, 2002). Thus, the inaccessibility of African film on specialist world cinema platforms such as Mubi would 
suggest that online distribution merely represents a change in the delivery of film, rather than a shift in the range of films delivered. Alongside this, specialised African film VOD sites remain preoccupied with recently-produced, commercial cinemas, further crowding out a socially conscious tradition of filmmaking that extends back over fifty years of the continent's history.

However, in the early days, or more precisely for a brief period between 2009 and 2013, it seemed that this tendency would be fundamentally challenged by the formation of the African Film Library (AFL). Established by a subsidiary of the South African TV network M-Net (Electronic Media Network) and managed by digital TV service DSTV Online (Cooper 2012), the AFL was a curated collection of over six hundred examples of canonical African cinema, providing non-geo-blocked access to the digitally remastered films on a pay-per-rental basis. The collection promised to be diverse, not only featuring the entire bodies of work by Sembene and Mambéty, but also less well-known but socially important films such as Idrissa Ouédraogo's Le Cri du coeur (1994) and Kwaw Ansah's Heritage Africa (1989). ${ }^{1}$ In this sense it promised to be of great value not only in terms of promoting African cinema to new audiences, but also from archival and educational perspectives, establishing an accessible repository of key African films that enabled users to instantly engage with them in a way that posed no threat to their preservation. Indeed, one thing that differentiated AFL from other VOD sites offering African films was its apparent disengagement from the market; it appeared to be committed to the promotion and preservation of African cinema's history first and foremost. In contrast, the majority of African VOD sites have tended to operate as a means of showcasing works by a new generation of digital filmmakers, whose films are designed to appeal to popular audiences and - perhaps just as importantly - already exist within a format that is suitable for digital distribution.

In this sense, the AFL represented a major archiving project that was set to transform our engagement with African film culture. Indeed, some of the initial reflections on the establishment of AFL saw it in terms of its social value, with Cornelius Moore suggesting that 'the original idea behind the African Film Library was to reach customers only on the African continent' even though 'the reality is that the Internet makes borders porous' (Moore 2010: 229). This 'domestic address' seemed particularly vital to a continent that had historically been excluded from the exhibition of its film output, echoing Ousmane Sembene's life-long commitment to touring his films around villages in the bush (Murphy 2000: 238); in this regard, the AFL represented a major shift of address towards domestic spectators, in addition to the established art house and festival audiences. However, by 2012 the global reach of the AFL had become a key priority, with the library's founder, MNet's head of sales Mark Dearham, remarking '[i]n making this content digitally accessible we are able to reach audiences right across the African Diaspora as well as to individuals with an interest in the continent's wealth of culture, history and film - showcasing the quality of African film to the global audience and challenging preconceptions' (in Graziadio 2012). Meanwhile, general manager at DSTV Online Jason Probert commented that ' $[t]$ his initiative will offer a radical pan-African solution to the historic challenge of distribution.... We hope that by helping to preserve and grow the African film industry,

\footnotetext{
${ }^{1}$ At the time of writing, the AFL still has a Youtube channel at https://www.youtube.com/user/AfricanFilmLibrary/videos?disable polymer=1. The channel holds trailers and clips from the movies that were held at AFL, and gives a sense of the scope and range of productions that were available.
} 
and by making it accessible to not only Africa, but the world at large, we are taking a step in the right direction' (in Anon 2009). The scope of the AFL to change perceptions of African cinema and Africa in general was clearly not lost on its founders, and indeed it was a major aspect of the PR case that surrounded its inception.

One of the less obvious - but probably most significant - ways in which the AFL might have 'challenged preconceptions' was through its cataloguing structure, whose organization meant that the movies reached users through a very different genre matrix to that which had previously shaped the international reception of the films. Canonical African cinema has long been conceptualised as either part of a postcolonial film project within the rubric of Third Cinema (see Armes: 1987: 189-226), or alternatively as an auteur-based cinema produced through transnational cooperation between African and European countries (as studies of individual directors demonstrate, including Armes 1987: 281-292; Murphy 2000; Murphy and Williams 2013; Petty 1996). As a result, where African films are not situated within a wider culture of anti-colonial filmmaking, there is a tendency to situate them in auteur-based terms, defining 'Sembene films' or 'Cissé films', rather than 'Senegalese films' or 'Malian films'.

The AFL approach undermined these tendencies, categorizing the works under headings that emphasized their heterogeneity, and potentially constructing a more nuanced 'map' of the continent's production. Not only were users able to search for films by director, but also by language, country of production, and - perhaps most importantly - by genre, delineating the works in terms of common categories such as comedy, drama, and thriller. This approach presented a potential reframing of African film culture, providing a model that identified narrative similarities and differences between the range of films produced across the continent, in addition to the more obvious differentiations between particular filmmakers, languages, and countries of production. Of course, part of the reason for this approach relates to user expectations of online delivery platforms, the structures of which demonstrate striking similarities because they are often provided by aggregators such as Under the Milky Way (supplier to iTunes), who design the library systems and determine the common filters used to categorise material offered across a range of VOD sites (Vonderau 2013: 105). Such categorizations also function to provide a way of navigating the vast array of texts available on sites like the AFL, thus providing ease of use in line with user expectations (since most users will already have some familiarity with this type of system). Thus, expectations about the organization of online cinema, coupled with the sheer amount of material available, result in a potentially unintended consequence in which a body of work is categorized in completely new ways.

These library systems thus form a matrix through which our perception of particular film cultures might be shaped, invoking new connections between often disparate texts. The potential of online distribution to affect the way cinema enters the public consciousness has been proposed by Lobato, who argues that:

[d]istribution lends itself to critical/cultural critique as well as industrial analysis because it ultimately functions to regulate access to texts, the conditions under which they are accessed and the range of texts available. In this way, distribution works to shape film culture in its own image (2009: 169).

From this perspective, evolving distribution practices shape film cultures by providing new ways of thinking about the relationships between texts. As Lobato and Ryan argue in 
relation to genre categorizations: '[a]ttention to the circulation of texts as material commodities in cultural markets, and to the structural and economic forces shaping movie genres as textual formations, industrial categories and production templates, can produce new models for genre analysis' (Lobato and Ryan 2011: 191). In this sense, the AFL presented the potential for a significant shift in the shaping of African film cultures, with genre emerging as a potential filter through which new forms of analysis might have emerged. For the first time, a set of texts historically homogenized under the rubrics of 'political cinema', 'Third Cinema' or 'African cinema' were delineated in terms of commercial genres, providing a system of categorization that also, to some extent, undoes the 'othering' of the films implicit in those homogenizing categories. Instead, the AFL matrix emphasizes the diversity of the work not only culturally, but also in terms of narrative and subject matter. Such a categorization also invites comparisons between African films and European and American genre films, potentially situating African film cultures alongside, and in some ways within, more 'mainstream' film cultures. In this sense, African films would be reframed within what Nagib et al see as a 'polycentric' approach to 'world cinema', which is contrasted to the centre/periphery binaryism that has so often framed the reception of cinema produced outside of Europe and America (Nagib et al 2012: xxii). Thus, the particular form of intermediation structured by the online distribution model had the potential to offer new ways of mapping African film cultures that avoided reductive binaries of difference.

Much of the argument above, however, falls into the 'cybertopia' narrative, in which the transformations of online distribution offer largely positive changes to the availability and visibility of niche cinemas. In reality, the AFI project raised a set of searching questions regarding the monopoly of ownership generated by the online model, questions that were amplified by the closure of the AFL in 2013. Behind the promise of improved availability of African cinema looms the threat of a monolithic company attaining top-to-bottom control of essentially scarce works; as access to the movies falls into private hands, questions emerge surrounding the new-found power accrued by private stakeholders in online distribution, and the extent to which the emerging technologies enable them to maintain a stranglehold on the material, in turn threatening the films' long-term availability as stakeholders respond to the demands of the market. As Lobato observes, ' $[\mathrm{t}]$ he potential for oligopoly is distressingly high in online VOD and the very real problem of access will need to be addressed' (2009: 176). Thus, the main problem with the AFL case was not so much that a particular archive ceased to exist, but that its technological model promoted monopolistic forms of control over its content. Whereas a physical library holding a copy of a film on DVD is also holding a right to archive and loan that copy, anyone purchasing access to a film on AFL was only purchasing a temporary pass to view the work. As a result, the films remained in the hands of the intermediary no matter who paid for access, giving the distributor a level of control over their content akin to the monopoly a distributor holds over a film's theatrical exhibition. Winston Wheeler Dixon echoes this problem in his remarks regarding a particularly well-known Amazon case:

But as events have proved, with streaming technology, even when you buy something, you don't really own it. An early harbinger of this was Amazon's now famous (and all too obviously ironic) deletion of George Orwell's 1984 from Kindles around the United States when the company discovered it had accidentally uploaded an unauthorized version of the novel (2013: 8, original emphasis). 
As Wheeler Dixon shows, the online distribution model offers the intermediary a level of control over content that is largely unprecedented. This is of particular concern in relation to scarce works - such as African films - where the short-term benefits of availability might blinker our perception of the long-term threats to their preservation. In tandem with this lies a potential disincentive for film archives to purchase physical copies of material; with budgetary and space limitations placing severe strains on libraries, the promise of the infinitely-capacious digital archive can seem very attractive. Yet in reality, a subscription to an online archive is no substitute for hardcopies of the material. Considering that stakeholders will respond to the demands of the market, and bearing in mind the ease with which online services may be 'switched off', one can easily imagine a situation emerging in which there no longer exists a 'back up' of a given film. Thus, once M-Net decided to pull the plug on AFL, the (in)availability of the films was left in exactly the same position as it had been before the site's inception. Indeed, there is an argument that the early death of the AFL was a blessing, stalling the site's opportunities to disrupt the hardcopy acquisition of the films by libraries and other archiving organisations.

Thus, the AFL provides a pertinent example of how - even with socially beneficial intentions - the streaming model is more likely to threaten the availability of niche films, rather than preserve it. Wheeler Dixon echoes these concerns in his words regarding Netflix's shift from a DVD-rental model to a streaming-only model, which he sees as a threat to the sustainability of older and less popular films:

'There's another major question lurking here: what about all the classic films that aren't available as streaming video? In essence, they will cease to exist. Netflix is banking on the fact that most people have no real knowledge of film history, so they'll content themselves with streaming only the most recent and popular films. This is something akin to Amazon deciding to do away with physical books altogether and offering everything only on Kindle. No doubt Amazon is thinking about this possibility and would love to do it, but this would marginalize hundreds of thousands of books. Netflix is doing the same thing with films. (2013: 5)

In the light of this, it is not difficult to understand why the case of the African Film Library raises so many concerns in relation to film archiving. Even though the service initially suggested that the preservation of African cinema might benefit from the market transformations offered by streaming distribution, this promise was easily negated by the possibility that the intermediaries might take the content offline at any moment.

In addition to its threat to film archiving, the online model has also opened-up new avenues of exploitation by distributors; in the case of M-Net, this manifested itself as a particularly aggressive use of market intelligence that anticipated the rise of long-tail markets and their potential benefit to niche cinemas. Thus, it was no surprise that the AFL project was met with considerable disquiet amongst filmmakers and critics, who saw the business practices of M-Net as highly exploitative. This was principally due to the fact that M-Net bought rights directly from African filmmakers (many of whom had been running their own production and distribution), as well as from foreign distributors in Europe. The purchases took the form of one off acquisition payments (wa Micheni 2009), which involved the procurement of all rights to the films, in perpetuity. The scale of the material that was purchased cannot be overestimated; one assessment suggested that AFL contained eighty per cent of the top African films ever made (wa Micheni 2009). Such was the level of concern among filmmakers and funding bodies that the issue was discussed 
at Cannes in 2007, where South Africa's National Film \& Video Foundation (NFVF) responded to M-Net's activities in wholly negative terms, arguing that ' $[\mathrm{t}]$ hese deals are effectively removing these films from circulation - monopolising their distribution' (in wa Micheni 2009). Indeed, Olivier Barlet pointed out that ' $[\mathrm{m}]$ ost of the filmmakers...sold the rights: it was direct money for films which did not bring anything anymore! They did not realise the value of them in the next years' (in wa Micheni, 2009). It seems that, unsurprisingly, most filmmakers were unaware of the value their works might accrue in the new world of long-tail markets; in the context of the old paradigm they had let them go at what seemed like a reasonable price. The NFVF went as far as to suggest that this had resulted in the elimination of entire bodies of work from circulation, inasmuch as 'many of the top African classics such as films by the late Djibril Diop Mambéty are inaccessible because of this arrangement' (in wa Micheni 2009).

Thus, the acquisition of these rights, and the mode of distribution adopted, represents a situation of extreme top-to-bottom control by a new kind of intermediary - one that holds an unprecedented level of power over its content. Arguably, if it were not for the existing library holdings of certain films, their circulation would now lie entirely in the hands of M-Net (which given their track record with AFL, would look extremely negative for future access to African cinema). The online model places a considerable amount of trust in the hands of the (new) intermediaries, who may pull the plug on their servers at any point, whether out of economic necessity or shifting priorities, as happened in reality with the AFL. It is still not known what will happen to the remastered material held by AFL, whether it will become available for streaming via another platform, be distributed through other means, or whether the rights will be sold on. At the very least, it appears that much of the work will remain unavailable for a considerable period of time. Thus, the combination of a monolithic approach to rights acquisition, coupled with the precarious nature of online holdings, suggests that the shift to a VOD model of exhibition represents a significant threat to the long-term preservation of African films, as well as niche material in general. This is partly because it promotes a potential shift in archiving practices, replacing a broadly-dispersed model in which a range of public and private organizations might hold copies of films, to one in which a single organization, driven by the interests of private capital, maintains an ever-tightening monopoly over the material.

What is particularly interesting about the case of the African Film Library is that it encapsulates the entire recent history of the critical response to 'digital disruption' in film distribution. Initially, it seemed to validate the 'cybertopian' narrative, raising the prospect that a neglected body of socially important works would finally be archived in a manner that resolved the conflicting needs of both preservation and availability. However, it also demonstrated how the prospect of disintermediation offered by the proliferation of online distribution quickly gave way to a new-intermediation, and that all that had really changed was the mode of dissemination. Eventually, the reality that presented itself demonstrated that in the new-intermediation, the intermediaries have even more control over content than the traditional distributers; far from democratizing film culture, distribution evolved to become even more monolithic, channelling material into ever-narrower circulation streams that are placed under increasingly tight controls (such as geo-blocking), with the potential to strengthen and loosen those controls as the market requires. It was only a matter of time, then, before the AFL situation reached its market-driven conclusion, with the archive falling offline and becoming completely inaccessible. The dream of cybertopia was met with a jarring reality in which short-term 
online accessibility threatened the long-term availability of niche material in any form at all.

The AFL case makes it clear, then, that the shift to online distribution presents specific challenges to the preservation of African film. On the one hand, we are forced to rethink the traditional paradigms that have structured the way we conceptualise African cinemas and global film in general, as an unprecedented range of material is presented to us through a variety of different platforms, and distinctions between different film cultures become increasingly blurred. However, we must also address the uncertainly threatened by the inevitable move towards a fully-online model, considering how the films are being preserved, who is holding them, and why. Motivated by private interest rather than public good, online modes of distribution have revealed themselves to be particularly suited to the needs of private stakeholders, and in turn have become even more precarious and limiting than orthodox distribution systems. The AFL case exemplifies both the specific and wider problems of these transformations, the full ramification of which are only just coming to light. 


\section{References:}

Anderson, C. (2006), The Long Tail: Why the Future of Business is Selling Less of More, New York: Hyperion.

Anon (2009), 'Africa's Largest Electronic Film Library Launched', Gauteng Film Commission, October 2009, accessed 12 January 2016.

http://www.gautengfilm.org.za/news/news-archive/2009/october-2009/568-africaslargest-electronic-film-library-launched.

Armes, R. (1987), Third World Film Making and the West, Berkeley and Los Angeles CA.: University of California Press.

Bisschoff, L. (2017), 'The Future is Digital: An Introduction to African Digital Arts', Critical African Studies 9, no.3, pp. 261-267.

Cooper, S. (2012), 'M-Net launches VOD African Film Library', Screen Daily, 26 March 2012, accessed 12 January 2016.

https://www.screendaily.com/m-net-launches-vod-african-film-library\$5039239.article

Cunningham, S. and Silver, J. (2012), 'On-line Film Distribution: Its History and Global Complexion', in D. Iordanova and S. Cunningham (eds), Digital Disruption: Cinema Moves On-Line, St Andrews: St. Andrews Film Studies, pp. 33-66.

Graziadio, M. (2012), 'Mnet Offers African Film Library On Demand', FilmContact.com, 26 March 2012, accessed 9 January 2016.

http://www.filmcontact.com/news/south-africa/mnet-offers-african-film-librarydemand

Iordanova, D. (2012), 'Digital disruption: Technological Innovation and Global Film Culture', in D. Iordanova and S. Cunningham (eds), Digital Disruption: Cinema Moves OnLine, St Andrews: St. Andrews Film Studies, pp. 1-31.

Kaufman, A. (2014), 'The Lonely Subtitle: Here's Why U.S. Audiences Are Abandoning Foreign-Language Films', Indiewire, 6 May 2014, accessed 21 February 2017.

http://www.indiewire.com/2014/05/the-lonely-subtitle-heres-why-u-s-audiences-areabandoning-foreign-language-films-27051/

Lobato, R. (2009), 'The Politics of Digital Distribution: Exclusionary Structures in Online Cinema', Studies in Australasian Cinema 3 (2), pp. 167-78.

(2010), 'Creative Industries and Informal Economies: Lesson from Nollywood', International Journal of Cultural Studies, 13 (4), pp. 337-354.

Lobato, R. and Ryan, M.D. (2011), 'Rethinking Genre Studies Through Distribution Analysis: Issues in International Horror Movie Circuits', New Review of Film and Television Studies 9 (2), pp. 188-203. 
Moore, C. (2010), 'US Distribution of African Film' in M. Saul and R. Austen (eds.), Viewing African Cinema in the Twenty-First Century, Athens, OH: Ohio University Press, pp. 225230.

Murphy, D. (2000), Sembène: Imagining Alternatives in Film and Fiction, Oxford: James Currey.

Murphy, D. and Williams, P. (2013), Postcolonial African Cinema: Ten Directors, Manchester and New York: Manchester University Press.

Nagib, L. Perriam, C. and Dudrah, R. (2012), 'Introduction', in L. Nagib et al (eds.), Theorizing World Cinema, London and New York: I.B. Taurus, pp. xvii-xxxii.

Petty, S. (ed.) (1996), A Call to Action: The Films of Ousmane Sembene, Westport CT: Praeger.

Tryon, C. (2013), On-Demand Culture: Digital Delivery and the Future of Movies. New Brunswick: Rutgers University Press.

Vonderau, P. (2013), 'Beyond Piracy: Understanding Digital Markets', in J. Holt and K. Sanson (eds.), Connected Viewing, New York: Routledge, pp 99-123.

wa Micheni, M, (2009), 'Why M-Net's Africa Film Monopoly is Causing Discomfort', Business Daily, 2 June 2009, accessed 12 January 2016.

https://www.businessdailyafrica.com/corporate/539550-605398-6nsc5fz/index.html

Wheeler Dixon, W. (2014), Streaming. Movies, Media and Instant Access, Lexington: University Press of Kentucky. 